\title{
Analysis on the Influential Factors of Japanese Economy
}

\author{
Tongye Wang ${ }^{1, \mathrm{a}}$ \\ ${ }^{1}$ School of Economics, the University of Sydney, Sydney, New South Wales, 2000, Australia
}

\begin{abstract}
Japan is known as a highly developed capitalist country. It was the third largest economy in the world by the end of 2017 and is one of the members of G7 and G20. Thus, for academic purpose, it is worth to discuss how Japan could expand the scale of its economy in different kinds of effective ways in the past half a century.

This paper will talk about the main factors to influence the Japanese economy from post-war period to twentyfirst century. The Solow-Swan model is used to target on explaining the factors that influence the long-run economic development in an economy. To present the effects that was brought by the past policies, both total GDP calculation and GDP per capita calculation are adopted as the evidence of economic success of Japan.
\end{abstract}

\section{INTRODUCTION}

After 1945, the world economy tends to be integrated due to the demands of post-war reconciliation. In this situation, the competitions and cooperation among countries become more intensive as time goes by. Under this premise, it is necessary for each country to have a better understanding on the development processes of its partners or competitors. In addition, it is also necessary for economic policy makers to understand the economic development histories of other countries, to learn from the valuable experiences then issue better economic policies in their own country.

This paper will identify five different sources of growth relevant to the history of Japan, those include: the post-war economic miracle from 1946 to 1954, the income doubling program from 1961 to 1970 , the agricultural basic law in 1961, the Bubble Economy of Japan in 1980s and the Plaza Acord in 1985. Besides, the detailed information about the events and policies will also be provided. After a brief discussion on the policies and events, the article will further illustrate what the predicted effects of these events or policies on GDP and GDP per capita are, then comparing with the actual effects to justify if the actual effects on GDP and GDP per capita the same as the predicted effects.

\section{POST-WAR ECONOMIC MIRACLE 1946-1954}

The World War Two had destructed the modernized process of development to the whole world, it also had brought a significant trauma to lead the Japanese economy to experience an inevitable economic recession. However, from 1946 to 1954, Japanese government had imposed a series of policies for developing their manufacturing industries further, and finally had achieved a huge success which brought Japan out of the previous stagnant situation. For this post-war economic miracle, relevant studies had figured out that the core of success is consisted with two principal proposes: first, the successful economic reform on adopting Inclined Production Mode. The Inclined Production Mode refers to being inclined to produce kinds of raw materials for final goods production, including steel, cotton and silks. It resulted the Japanese textile production occupied more than $23.9 \%$ of the total industrial production [9]. As the quality of all the final goods is necessary to be improved for exporting, the encouragement on producing raw materials thus could be defined as positive on further capitalizing. These final goods may include the autos and modern industrial machinery which were at the beginning stage of popularizing in the western world in post-war period. Second, to increase the labor participation rate hence stimulating production, Japanese government decided to support the recruitment of female employees, which were traditionally regarded as housewives. For instance, the great majority of workers who participated in the textile production were the young rural women [3]. Therefore, by increasing the overall participation rate, Japanese labor market had recovered immediately and thus brought enough labor force to production.

Based on the GDP model on demand side, when the Japan experienced the post-war economic miracle period, its total output level was predicted to increase with the growth on the quantities of both raw materials and employees. By consuming the produced intermediate goods for putting into final production, the overall consumption level would rise. As firms at post-war stage started to realize the importance of catching up the speed of industrialization, their willingness of investing on advanced machinery would become strong. Therefore, the total investment level would go up as well. As the overproduced good would be exported for currency 
exchanging, therefore, the net exportation level was predicted to rise. However, the output per labor would present a vague growing trend. As the investment increased, the total level of output would increase as well, but as more female workforce was instilled, thus, it is hasty to conclude that the level of output per labor would increase or not.

The actual effects of post-war were consistent with the previous predictions. In 1955, the level of Japanese GDP per worker is lower than the other mainstream western countries due to the post-war reconstruction, such as the United States and the United Kingdom. However, it presents an enormous increase on the growth rate of the same parameter in the next 35 years. The same situation also occurred on the GDP per capita. From 1955 to 1990 , Japan has achieved a growth rate on GDP per capita for approximately $6 \%$ [8]. Therefore, there is evidence to conclude that the economic miracle is an actual welldeserved miracle on the development of Japanese economy. It has a wider significance on the later Japanese economic growth. An example could be a comparison between the Germany and the Japanese GDP in 1960s. By the end of 1968, the Japanese GDP has achieved 141.9 billion dollar, which has exceeded the Germany GDP and been acknowledged as the second that compared with all the capitalized countries, though the German was presented to be more competitive than Japan with the assistance of the United States.

\section{INCOME DOUBLING PROGRAM 1961- 1970}

The Income Doubling Program in Japan from 1961 to 1970 has been successfully completed. It even exceeded its main goal of doubling the amount of average income of Japanese national citizen within ten years as well as increased the GDP and the GDP per capita of Japan significantly.

The Income Doubling Program is a program that published by the Japanese government in 1961. It focused on developing the Japanese national economy by adopting a series of fiscal and monetary policies which targeted on expending the scale of social capital, promoting international trade, and revitalizing technology industries to facilitate the GDP growth step by step. The Japanese official has announced that with the gradual boosting of this program, the Japanese country was expected to achieve a $7.2 \%$ growth on its average annual GDP growth rate, to double the amount of income of the Japanese national citizens within ten years, and to implement full employment domestically. As the Japanese government was seeking to improve the overall living standards of Japanese citizens [4], thus, instead of targeting on benefiting some specific regions, this policy was targeting on bringing the propensity to the whole Japanese country.

Basing on the GDP model on demand side, there is an evidence to predict that the investment factor would increase as the Japanese government was encouraging to accumulate the capital through public financing. Besides, with the subsequent activeness in global trading market after the adoption of the policy, the value of consumption and exportation would increase as well. As a result, the final outputs were predicted to increase, thus the GDP was predicted to increase as well. The same effects could also apply to the final improvement on the GDP per capita, as the accumulation of capital would raise the value of capital hence increasing the output per labor.

The actual effects of the Income Doubling Program were presented as a huge success beyond expectation. By the end of 1970, the actual average growth rate of the GDP has increased to $11.6 \%$ [5], and the actual GDP per capita in 1970 was 2.6 times than the value of GDP per capita in 1961 [6]. Therefore, the predicted effects are consistent with the actual effects.

\section{THE AGRICULTURAL BASIC LAW 1961}

The Agricultural Basic Law was enacted by the Japanese government to modernize the agriculture of the country in 1961. It attempted to increase the incomes of farmers by expanding the scale of farm operations, thus cutting production costs and raising farm productivity [10]. Therefore, even though the expected sales and consumption of some agricultural commodities were difficult to facilitate, by reducing the production costs, it was still possible to increase the income of farmers. In additions, during the implementation of the Agricultural Basic Law, the Japanese government has provided a considerable amount of loans to farmers to construct their farmlands efficiently and purchase agricultural machines through utilizing the central and local budgets. As the government was aiming to develop the modern Japanese agriculture further, this policy would occur specifically in the rural areas of Japan.

The predicted effects of the Agricultural Basic Law on the Japanese GDP and GDP per capita are similar to the predicted effects of Income Doubling Program. Basing on the GDP model on demand side, reducing on production costs of agricultural commodities would lead a lower price that attracts the consumers. Therefore, the predicted consumption would increase with the increased sales. Besides, the Japanese government has spent its budget on providing loans to farmers. Therefore, the government expenditure would rise in this situation. As a result, the predicted GDP in Japan should increase simultaneously. For the GDP per capita, as the Japanese farmers could utilize their received loans to purchase latest equipment for production, the overall efficiency which is represented as ' $\mathrm{E}$ ' in Solow model could increase. Therefore, an increasing on efficiency could also lead the GDP per capita to rise.

The actual effects were presented as same as the predictions. The value of Japanese GDP in 1986 was nearly thirty-nine times higher than the one in 1961 [5]. The value of Japanese GDP per capita in 1986 was nearly thirty times higher than the one in 1961 [6]. Therefore, the predicted effects are consistent with the actual effects. In conclusion, the Agricultural Basic Law was one of the most efficient policies that contributed to the Japanese GDP in 1960s, and it was crucial to both the buyers and 
the sellers who were benefited from lower prices and improved productivity.

\section{THE BUBBLE ECONOMY 1980S}

The term Bubble Economy is equivalent to the deceitful boom of an economy. From 1980s, due to the dramatic exchange rate changes and deflation, there were several speculations occurred in Japanese domestic market, especially in the stock and land trades. The Bubble Economy was a special case that occurred in the whole Japanese country. With the unimaginable continuous rise on the price of lands, the number of transactions on buying then reselling the lands has increased in multiples hence leading to a high housing prices in housing market, and the same situation also occurred on stock trades [7]. For instance, in 1987, the Japanese land value of assets had been increased to 1638 thousand billion dollars, which had exceeded as four times as the value of the United States at the same time [1]. However, without the support of Japanese entity economy which should follow the same pace with the growing on investments, the Bubble Economy would not live as long as a legend. As the bank of Japan began to implement financial austerity, the number of speculations would decrease, and lead the prices of lands and stocks to fall down rapidly. Therefore, the amount of debts had to increase, the consumer losses exceeded the consumer surpluses, the 'bubble' had to burst immediately in the end.

In some ways, the predicted effects of the Bubble Economy are expected to be positive. With the increased prices of lands and stocks, the total investments were supposed to increase. As people were used to purchasing more in market through reselling the properties to the others, the total consumption was supposed to increase as well. As a result, the Japanese GDP was supposed to increase in 1990s. In additions, once the investments on lands and stocks increased, the amount of capital would be expected to increase as people would construct and rebuild on their purchased lands. Therefore, the Japanese GDP per capita was supposed to increase as well in 1990s.

The actual effects of the Bubble Economy were positive during the occurred period of the event. However, once the event finished, the value of Japanese GDP and GDP per capita started to decline in 1995. From 1995 to 1998 , the value of GDP had decreased nearly 26 percent and the value of GDP per capita had decreased 27 percent. Although the event was happened in 1908s, its effects could even last to influence the economy of a country in the next decade [6]. Therefore, the Bubble Economy slowed the Japanese economy down once its period has passed.

\section{THE PLAZA ACORD IN 1985}

In the early $1980 \mathrm{~s}$, the fiscal deficit of the United States soared, and the foreign trade deficit increased sharply as well. The United States would like to increase the export competitiveness of its products through the depreciation of the US dollar, so as to improve the balance of payments of the United States.
On September 22, 1985, the United States, Japan, federal republic of Germany, France and the finance ministers of the Britain and central bank governors (G5) held a meeting in plaza hotel in New York, and a contract was signed by the joint five governments which would like to intervene in currency markets. The aim of this contract was that leading the US dollar to depreciate hence leading the exchange rates of world major currencies to devalue orderly, in order to solve the problem of huge trade deficit of the United States. The agreement is also known as the plaza agreement as it was signed at the plaza hotel.

In September 1985, the United States dollar fluctuated around 250 yen per dollar. Within three months after the signing of the agreement, the United States dollar quickly fell to about 200 yen per dollar, which had achieved a drop of $20 \%$. After this significant changing, the U.S. authorities, led by the U.S. Treasury secretary, the financial experts, and the director of the American institute of international economics all continued to verbally intervene in the exchange rate of the United States dollar, which had fallen as low as 120 yen to the dollar. In less than three years, the dollar has lost $50 \%$ of its value against the yen, which means the yen has doubled in value against the dollar.

This action had led to bringing a huge foreign investment into the Japanese capital market. At the end of 1986, the dollar was trading at 152 yen, and in 1987 it peaked at 120 yen. From February 1985 to November 1988, the nominal exchange rate of the Japanese yen against the United States dollar had increased by $111 \%$. From April 1990 to April 1995, the Japanese yen had appreciated by $89 \%$. Between August 1998 and December 1999, it appreciated by $41 \%$. From the first quarter of 1985 to the first quarter of 1988 , the real exchange rate of the yen appreciated by $54 \%$. From the second quarter of 1990 to the second quarter of 1995 , it appreciated by $51 \%$. From the third quarter of 1998 to the fourth quarter of 1999 , it increased by $28 \%$. Therefore, there is evidence to present that the signing of the Plaza Acord had successfully attracted the U.S. dollar imported into the Japanese capital market and stimulated the needs of investing on both real estate market and the stock market [1]. However, this economic legend could not last forever as the resources and powers that were owned by all the governments were limited. It is impossible to achieve economic prosperity solely through controlling on market prices by controlling currency exchange rates. Starting from the mid-to-late 1980 s, with the bursting of the Bubble Economy, Japan fell into a decade-long period of economic stagnation, which is known as the Lost Decade in the later decades [2].

The predicted effects of the Plaza Acord in 1985 were positive. According to the GDP function on demand side, once the Japanese currency yen appreciated, the nominal income of Japanese domestic employees would increase as well. With the increase on income level, the purchasing power would increase either. In other words, Japanese domestic employees would purchase more than before. Therefore, the consumption level would rise after the implementing of the Plaza Acord. On the other hand, as more the United States dollar was attracted to flow into the Japanese capital market, the level of foreign investment would increase as well. Therefore, the level of net 
exportation of Japan would decrease, but it not significant enough to influence the overall increasement on the total output in accordance with the GDP calculation equation on demand side. Similar situation was also predicted to occur on the level of output per capita. With the increase on the quantity of foreign investment, the level of the capita per labor would increase hence stimulate the level of output per labor to rise.

The actual effects were consistent with the previous predictions. From 1985 to 1990 , the value of Japanese GDP had increased approximately by 1.3 times, the exact numbers were presented as 1399 and 3133 billion dollars respectively [5]. The level of GDP per capita also presented its consistency with the previous prediction. From 1985 to 1990, the value of Japanese GDP per capita had increased approximately 1.2 times, the exact numbers were presented as 11585 and 25359 dollars respectively [6]. Therefore, there is enough evidence to prove that the actual effects of the Plaza Acord on Japanese GDP and GDP per capita are illustrated as same the predicted ones.

\section{CONCLUSION}

In conclusion, the predicted effects on the Post-war economic miracle 1946-1954, Income Doubling Program, the Agricultural Basic Law and the 'Bubble Economy' were demonstrated as positive. All the effects could increase the GDP and GDP per capita in particular period in Japan. However, the actual effects that have been proved by the real data from the officials were not all consistent with the predicted effects. For the Post-war economic miracle 1946-1954, the Income Doubling Program, the Agricultural Basic Law and the Plaza Acord in 1985, the actual effects were presented as the increases on the GDP and GDP per capita in specific period. For the 'Bubble Economy', the actual effects were presented as increasing the GDP and GDP per capita temporarily, when the government intervened, both the GDP and GDP per capita started to decrease immediately.

\section{ACKNOWLEDGMENT}

First and foremost, I would like to show my deepest gratitude to my teachers and professors in my university, who have provided me with valuable guidance in every stage of the writing of this thesis. Further, I would like to thank all my friends and roommates for their encouragement and support. Without all their enlightening instruction and impressive kindness, I could not have completed my thesis.

\section{REFERENCES}

1. L. Bai. The Japanese Real Estate Bubble Formation and Collapse and its Enlightenment to China. Dongbei University of Finance and Economics. 2011. Accessed December 15, 2019. China HowNet.

2. C. F. Bergsten and R. A. Green, eds. International Monetary Cooperation: Lessons from the Plaza Accord after Thirty Years. Washington DC: Peterson
Institute for International Economics, 2016. Accessed August 17, 2019. ProQuest Ebook Central.

3. M. C. Brinton. Women and the Economic Miracle: Gender and Work In Postwar Japan. Berkeley: University of California Press. 1992

4. Economy Planning Agency. 'Income Doubling Program 1961-1970'. Planned Economy Research (1985): 36-45. Accessed July 25, 2019. http://xueshu.baidu.com/usercenter/paper/show?pape $\mathrm{rid}=\mathrm{cfb} 8 \mathrm{c} 9 \mathrm{~d} 0 \mathrm{ecb} 52 \mathrm{e} 031 \mathrm{a} 85 \mathrm{aa} 5 \mathrm{fc} 58288 \mathrm{c} 7$

5. Fast Easy Financial Web. 'Historical GDP Data of Japan'.

https://www.kuaiyilicai.com/stats/global/yearly_per_ country/g_gdp/jpn.html

6. Fast Easy Financial Web. 'Historical GDP per capita Data of Japan'. https://www.kuaiyilicai.com/stats/global/yearly_per_ country/g_gdp_per_capita/jpn.html

7. M. Iyoda. Bubble Economy and Its Generation' In: Postwar Japanese Economy.Berlin: Springer. 2010, pp: 69-79. Accessed July 25, 2019. https://linkspringer-

com.ezproxy1.library.usyd.edu.au/chapter/10.1007/9 78-1-4419-6332-1_7\#citeas

8. R. Katz. Japan, the System That Soured. New York: Routledge. 1998, pp: 107-164. Accessed August 10, 2019. https://doiorg.ezproxy1.library.usyd.edu.au/10.4324/97813157 03213

9. B. Seymour. Industrial dualism in Japan: a problem of economic growth and structural change. Chicago: Alpine Publication Corporation. 1966, p: 39.

10. K. Yamashita. The Political Economy of Japanese Agricultural Trade Negotiations. In: The Political Economy of Japanese Trade Policy. Critical Studies of the Asia-Pacific. 2015, pp: 71-93. Accessed July 25, 2019. https://link-springercom.ezproxy1.library.usyd.edu.au/chapter/10.1057/9 781137414564_3\#citeas 